\title{
Leão Hebreu: entre Moisés e Platão
}

\section{Resumo}

\section{Cicero Cunha Bezerra* Gilmar Araujo Gomes**}

Não é novidade dizer que os Diálogos de Amor, de Leão Hebreu, é um texto que remonta a uma longa tradição espelhada na obra $O$ banquete de Platão. Sua temática, estrutura narrativa e, porque não dizer sua finalidade, isto é, caracterizar o ideal de sabedoria mediante a reflexão sobre os vários tipos de eros, o faz expoente, no contexto renascentista, do que poderíamos nomear de um entremeio em que elementos gregos e judaicos dialogam em harmonia. O objetivo desse nosso trabalho consiste, assim, em revelar os vínculos comuns entre os Diálogos de Amor e o comentário de M. Ficino ao Banquete de Platão buscando, com isso, apresentar os aspectos comuns e distintos que vinculam o pensamento de Hebreu à tradição ficiniciana de tonalidade neoplatônica e, também, o separa, ainda que de modo velado, ao direcionar todo o seu esforço interpretativo para o ideal de experiência original de sábio associada diretamente à experiência serfadita ou marrano-bumanista.

Palavras-chave: Serfadita, Marrano, Amor, Banquete, Marsilio Ficino, Leão Hebreu.

\section{Leão Hebreu: between Moses and Plato}

\section{Abstract}

It is no novelty to say that the Dialogues of Love by Leão Hebreu is a text that goes back to a long tradition mirrored in Plato's Banquet. Its thematic, narrative structure and, why not say its finality, that is, to characterize the ideal of wisdom by reflecting

* Universidade Federal de Sergipe. Departamento de Filosofia. Programa de Pós-Graduação em Filosofia e Programa de Pós-Graduação em Ciências da Religião UFS. Pesquisador de Produtividade PQ/CNPQ. Departamento de Filosofia. Pesquisador do CNPq (2013/ Atual). Autor dos livros Compreender Plotino e Proclo, Petrópolis;Vozes, 2006. Mística e Neoplatônismo em Dionísio Pseudo Areopagita, São Paulo: Paulus, 2009.

** Mestre em Ciências da Religião pela Universidade Federal de Sergipe (UFS). Bacharel em Teologia pela Universidade Presbiteriana Mackenzie - Escola Superior de Teologia (2008). Bacharel em Teologia pelo Seminário Teológico Presbiteriano "Rev. José Manoel da Conceição" (2004). Licenciando em Filosofia pela UFS. Membro associado do GPDAS/ UFS - Grupo de Pesquisa Diáspora Atlântica dos Sefarditas / Universidade Federal de Sergipe. Membro associado do OBSERVARE/UFS - Observatório Multidisciplinar de Religiões e Religiosidades / Universidade Federal de Sergipe. 
on the various types of eros, makes it an exponent in the Renaissance context of what we might call an intertwining in which Greek elements and Jews dialogue in harmony. The purpose of our work is thus to reveal the common links between the Dialogues of Love and M. Ficino's commentary on Plato's Banquet, thereby seeking to present the common and distinct aspects that link Hebreu's thinking to the Ficinian tradition of neoplatonic tonanility, and also, separates him, albeit in a veiled way, by directing all his interpretative effort to the ideal of the original experience of the sage directly associated with the Sephardic or Marrano-humanist experience.

Keywords: Sephardic, Marrano, Love, Banquet, Marsilio Ficino, Leão Hebreu.

\section{León Hebreo: entre Moisés y Platón}

\section{Resumen}

No es nuevo decir que los Diálogos de Amor, de León Hebreo, es un texto que se remonta a una larga tradición reflejada en la obra El banquete de Platón. Su temática, estructura narrativa y, por qué no su finalidad, es decir caracterizar el ideal de sabiduría mediante la reflexión sobre los varios tipos de eros, lo hace exponente, en el contexto renacentista, de lo que podríamos nombrar de un medio término en que elementos griegos y judaicos dialogan en harmonía. El objetivo de nuestro trabajo consiste, así, en revelar los vínculos comunes entre los Diálogos de Amor y el comentario de M. Ficino al Banquete de Platón buscando, con eso, presentar los aspectos comunes y distintos que vinculan el pensamiento de Hebreo a la tradición ficiniciana de tonalidad neoplatónica y, también, lo separa, aunque de modo velado, al dirigir todo su esfuerzo interpretativo hacia el ideal de experiencia original de sabio asociada directamente a la experiencia sefardita o marrano-bumanista.

Palabras clave: Sefardita, Marrano, Amor, Banquete, Marsilio Ficino, León Hebreo

SOFIA - Muito me agrada este discurso. M/ as como me consolarás acerca de Platão, que, sendo quem é, nega que em Deus haja amor? FILON - Sobre a forma de amor discutida no Simpósio (apenas o que é participado aos homens), Platão fala verdade, porque um tal amor não pode existir em Deus, mas seria falso afirmar que não há em Deus o amor universal de que estamos a falar.

Diálogo Terceiro: Sobre a Origem do Amor

(ABRAVANEL, 2001, p.258)

\section{Considerações iniciais}

Não é novidade dizer que os Diálogos de Amor, de Leão Hebreu, é um texto que remonta a uma longa tradição espelhada na obra $O$ banquete de Platão. Sua temática, estrutura narrativa e, porque não dizer sua finalidade, isto é, caracterizar o ideal de sabedoria mediante a reflexão sobre os vários tipos de eros, o faz expoente, no contexto renascentista, do que poderíamos nomear de um entremeio em que elementos gregos e judaicos convergem, 
em uma experiência original de sábio associada diretamente experiência serfadita ou marrano-humanista. ${ }^{1}$ Essa forma de expressão da linguagem, que reúne experiência pessoal gerando um ensino compartilhado com muitos, foi entendida pelo pesquisador Andrés Soria Olmedo (2009) como uma característica de "duplicidade" na obra de Leão Hebreu, assim registra Jacqueline Savoye de Ferreras (1985, p. 169). Analisando a obra de Andrés Olmedo em crítica aos Diálogos de Amor, a autora explica que essa duplicidade vista por Olmedo é apenas aparência, pois os Diálogos de Amor foram compostos conforme as normas que os dialogistas espanhóis do séc. XVI observavam e que consistiam em "fazer falar os personagens a partir de sua própria experiência, para dar testemunho convincente da verdade de suas palavras, o que resulta lógico - e necessariamente - que o que fala de amor está enamorado" (SAVOYE DE FERRERAS, 1985, p. 169). Deste modo, para fazer-se crer na mensagem que busca transmitir, Leão Hebreu apresenta constantemente uma dupla estrutura, ou seja, expõe as características de sua teoria do amor enquanto Fílon expressa seus sentimentos por Sofia. Noutro estudo, James Novoa (2005) reafirma esta dupla estrutura literária quando também percebe que os temas transcendentais nos Diálogos de Amor são tratados pelos interlocutores "enquanto se desenvolve a relação concreta de Fílon e Sofia, do amante efusivo e da amada fugidia. Ao tempo em que discorrem doutrinas e temas filosóficos, o leitor nunca perde de vista o pano de fundo que é o amor insatisfeito de Fílon" (NOVOA, 2005, p. 107). E assim Leão Hebreu se utiliza do personagem Fílon para expressar suas vivências, o conjunto de experiências e sabedoria de um sefardita errante; imagem essa tão recorrente no Cântico dos cânticos, bem como em todo um conjunto de autores ligados, por um lado, ao trovadorismo medieval em seu aspecto profano e a lírica italiana que remonta à poesia petrarquista e, por outro, às narrativas mística, de matriz neoplatônica, também baseadas no Banquete e no eros como intermédio entre a alma e o Uno, estruturalmente

\footnotetext{
A expressão "marrano-humanista" encontrada em Luiz Alves (1997, p.107) faz referência à ambiguidade de sentidos que ele entende haver em Fílon, sujeito narrativo masculino dos Diálogos de Amor, que "pretende resolver as dúvidas falando de modo 'universal"' (ALVES, 1997, p. 107), mas que sempre tem dificuldade de se expressar à Sofia, sujeito narrativo feminino, em meio ao enfrentamento da vida civil. Embora a expressão marrano-bumanista não seja apresentada por Luiz Alves como um subtítulo de identificação, aqui estou separando-a como tópico que pode exprimir a designação de um gênero literário próprio dos sefarditas do Renascimento em suas mensagens de cunho esotérico com ênfase na manutenção da posse de um segredo, só percebido aos iniciados nas mesmas esperanças. Um conceito a ser ampliado a posteriori.
} 
fundamentadas no Cântico dos cânticos e na incompletude radical que separa amante (alma) e amado (Deus) ${ }^{2}$.

Como já observado, com a definitiva expulsão dos judeus dos reinos de Espanha e Portugal, respectivamente, "os judaizantes aproveitaram toda oportunidade para emigrar para a Itália, África e Turquia” (WIZNITZER, 1966, p.2). E foi assim que a diáspora dos Abravanel teve rumo à Itália, chegando em Nápoles pouco antes do fim de 1492. E por que a família Abravanel escolheu Nápoles? Luiz Alves (1997) esboça uma resposta:

Na geografia do pensamento italiano na saída medieval, Nápoles é um centro epicurista, Padova, Bolonha e Ferrara são expoentes do averroísmo peripatético, enquanto Firenze e Toscana se alinham ao platonismo. Roma se aproxima de Nápoles (...), com a variante importante do poder religioso. (...) É necessário lembrar que durante a maior parte da Idade Média os judeus viveram abaixo de Roma, caminhando no rumo do norte na evolução para a Modernidade. Associe-se essa presença à familiaridade da corte espanhola no reino de Nápoles e se terá o quadro de preferência por essa cidade. (ALVES, 1997, p. 28)

Talvez Nápoles, em seu aspecto epicurista, ancorado em uma experiência de liberdade e autodomínio frente ao conflito, tenha favorecido, graças à abertura para outras crenças, que Judá Abravanel encontrasse o ambiente marcado pela cultura judaica com forte presença de intelectuais e humanistas de grande porte, além de grande interesse pela tradição interpretativa da Cabala. Em atendimento a este interesse, seu irmão mais novo, Samuel, abriu a casa familiar para realizar sessões de estudos de temática cabalística (ABRAVANEL, 2001, p.18-21). A sólida formação intelectual recebida em Lisboa permitiu a Leão Hebreu iniciar um processo de abertura cultural na Itália rumo ao sincretismo de método especulativo que incluiria, “além da Bíblia hebraica e dos grandes Comentários Talmúdicos [...] as obras mais significativas de autores tais como Maimônides ou Averroes, para lá dos escritos de Aristóteles e dos seus comentadores mais antigos" (ABRAVANEL, 2001, p.12). Também em Nápoles, Leão Hebreu aproximou-se de Judá ben Yehiel, Elia del Medigo (ca. 1460-1497), ${ }^{3}$ assíduo leitor de obras cabalísticas,

2 Sobre o tema ver:BEZERRA, C.C e BEZERRA, J.S.C. A Linguagem nupcial no "Cántico espiritual" de San Juan de La Crur, Texto disponível em: https://periodicos.ufsm.br/letras/ article/view/6903

3 Além de indicar del Medigo como médico e provável professor na Universidade de Pádua, James Novoa (2009a) informa que ele, sendo de origem aschkenazita, "era um Averroista declarado, (...). Além de ser o instrutor de [Giovanni] Pico, del Medigo traduz obras 
e Jochanan Alemanno. ${ }^{4}$ Com todo esse processo de familiarização, ${ }^{5}$ é possível reconhecer o clã Abravanel como intermediários culturais nesta diáspora sefardita em ambiente renascentista italiano.

Os Diálogos de Amor foram compostos na Itália, muito provavelmente em Gênova, ${ }^{6}$ novo local de refúgio, para onde Leão Hebreu acudiu depois que Carlos VIII entrou em Nápoles expulsando os judeus em fevereiro de 1495. Pela primeira vez, Judá Abravanel separou-se de seu pai e mentor, que seguiu para Ferrara com a outra parte da família, passando a viver a experiência da solidão no exílio. Em meio a este ambiente de interações culturais renascentistas, expulsão de Sefarade, dispersão na Itália, separação da família, e saudades do filho retido à força em Portugal, os Diálogos de Amor são produzidos. O pesquisador Joaquim de Carvalho, citado em Paula Tavares (2011), completa esse entendimento:

filosóficas para ele, nomeadamente obras de Averroes, e traduções hebraicas dos textos originais árabes, para o latim. Ao mesmo tempo que louvava o interesse de Pico pelo pensamento averroístico e aristotélico, opôs-se ao aluno que se interessava, cada vez mais, pela interpretação alegórica dos textos sagrados contidos no corpus dos textos reconhecidos como cabalísticos, separando-se dele em finais de 1486" (NOVOA, 2009a, p. 76,77).

4 NOVOA (2009a, p. 78, nota 8) indica uma extensa bibliografia referente à obra de Alemanno. Para o pesquisador português, o aschkenezita Alemanno "descendia do último rabino de Paris antes da expulsão dos Judeus da França em 1348 (...). [E operava] uma síntese de várias correntes filosóficas como o neo-platonismo, o aristotelismo e o verroísmo, com a sua particular interpretação da Cabbalah" (NOVOA, 2009a, p. 78).

5 Sobre esta adaptação no exílio, Vila-Chã indica que foi "um intenso processo de familiarização não apenas com alguns dos mais proeminentes intelectuais judeus do Renascimento, mas também com um dos círculos intelectuais mais distintos de todo o movimento humanista do Renascimento, nomeadamente com aquele que se aglutinava em torno de Giovanni Pontano (1426-1503)" (ABRAVANEL, 2001, p. 21).

6 Leão Hebreu embutiu em seu texto alguns marcos temporais que ajudam a identificar o período em que ele escrevera sua obra. Nos Diálogos Primeiro e Segundo, por exemplo, ele faz referências à "recente navegação de Portugueses e Espanhóis" (ABRAVANEL, 2001, p. 92, 138), cujos relatos trazidos à Europa ampliavam seus argumentos sobre os pólos Ártico e Antártico, e a descoberta "de mais estrelas fixas no céu e mais lugares habitados na Terra." (ABRAVANEL, 2001, p.138). Também registra ALVES (1997, p. 33): "Santino Caramella, nos Dialoghi d'Amore por ele editados, pensa que os dois primeiros diálogos tenham sido escritos em Gênova, pois ali também [Leão Hebreu] passou seis anos. Na parte três dos Dialoghi d'Amore encontramos a indicação do ano judaico 5262, que ocorre entre o outono de 1501 e o verão de 1502.” Distinto de Caramella, outrossim, Vila-Chã relaciona o ano 5262 "ao período de tempo compreendido entre Outono de 1501 e o Outono de 1502.” (ABRAVANEL, 2001, p.25). Esta referência temporal para datar a criação do universo como ano 5262 "segundo a verdade hebraica" (ABRAVANEL, 2001, p 284), entendemos ser uma forma de Leão Hebreu registrar consonância entre o calendário hebraico e o europeu vigente, marcando a data da escrita do Diálogo Terceiro. 
Nesta cidade [de Gênova], jovem ainda, morre-lhe o segundo filho, e a necessidade, ao que parece, obriga-o a exercer a medicina (donde o ser conhecido por Leão Médigo); mas apesar destas provocações, tudo leva a crer que escrevesse neste período os Diálogos de Amor e o De cali harmonia, e convivesse com Francisco Pico, sobrinho do célebre João Pico. (CARVALHO apud TAVARES, 2011, p.16)

Neste locus de sentidos múltiplos, vivia-se uma Renascença de conceitos, um período que tem servido a divergentes interpretações atuais quanto ao papel do homem como centro de referência da vida e a aceitação de que, "entre a Idade Média e o Renascimento, houve continuidade e não ruptura" (CARVALHO, 2012, p. 28). ${ }^{7}$ Em sua proveitosa publicação sobre Fé e Razão na Renascença: uma introdução ao conceito de Deus na obra filosófica de Marsílio Ficino, Talyta Carvalho (2012) apresenta as variações de um debate prolongado sobre o continuísmo ou ineditismo da Renascença em comparação com a assim chamada Idade das Trevas. Evocando recentes e conceituados acadêmicos que debatem o Renascimento, a autora dedica um de seus capítulos para apresentar as questões e controvérsias em torno do debate sobre o tipo de humanismo encontrado no período de elaboração de O Livro do Amor e, principalmente, dos Diálogos de Amor, preocupação desta pesquisa.

Em sua análise, Talyta Carvalho (2012) apresenta as considerações da corrente teórica que entende a Renascença como expressão de um movimento humanista filosófico, "a filosofa do homem”, como propôs James Hankins, uma perspectiva filosófica que reduzia o divino ao humano, opondo-se a dogmas religiosos e circunscrevia o homem a uma entidade biológica (CARVALHO, 2012, p. 30,31). Do outro lado está a corrente que formula o termo 'humanismo' como uma ênfase aos estudos dos clássicos gregos e latinos, enfatizando o conteúdo da educação clássica que marcou o período. A bem da verdade, a pesquisa de Paul Kristeller ressalta que os próprios renascentistas não se entendiam 'humanistas', sendo o 'humanismo' uma palavra cunhada em 1808 pelo educador F. J. Niethammer em referência à educação clássica exercida no período renascentista (CARVALHO, 2012, p. 30). Assim, referir-se ao humanismo renascentista, stricto sensu, deve ser uma menção a um programa cultural e educacional aplicado na Renascença, as studia bumanitatis, e limitado aos estudos literários das obras da antiguidade clássica. 7 A frase citada é de Paul Oskar Kristeller que é apresentado pela autora como "a maior
autoridade" em estudos da Renascença, conforme avaliação atual dos scholars. 
Somado ao debate entre Kristeller e Hankins, acresce-se Hans Baron, outro especialista em Renascimento, que propôs o humanismo como um movimento intelectual de consequências políticas. Por esta corrente, os florentinos de 1400 inauguraram um 'humanismo cívico', propondo medidas de proteção às ameaças de invasão que Florença sofria, levando os intelectuais e cidadãos a repensarem seus posicionamentos cívicos e ações políticas. "Em resumo, para Baron, o 'humanismo cívico' representou, sim, uma ruptura clara com a cultura medieval" (CARVALHO, 2012, p. 38,39), por permitir o repensar das ações humanas no domínio de suas disposições políticas e de afirmação pessoal.

Filosófico, literário ou cívico, o humanismo do Renascimento, explica Lacruz (2006), não pretendia uma ruptura com o cristianismo, antes se valia das fontes clássicas antigas para considerar possibilidades teóricas e assimilação de elementos até então incompatíveis com o cristianismo. "Entre as ideias pagãs revitalizadas figuram: a confusão entre o 'amor' cósmico e o psíquico, a imersão do amor no mitológico e mágico, e a mística neoplatônica mesclada com o panteísmo" (LACRUZ, 2006, p. 119). Ressalta-se que estas ênfases são encontradas na obra de Leão Hebreu, sobretudo no Diálogo Terceiro, o que ajuda a configurar os Diálogos de Amor como obra típica do humanismo no Renascimento.

Ainda que a condição multifacetada do Renascimento tenha aberto espaço para a reconsideração de conceitos pitagóricos, neoplatônicos, místicos e elementos greco-pagãos, não significou esse tempo um total desprezo à visão cristã de vida e amor (LACRUZ, 2006, p. 114). Entre os que se propuseram a favorecer um renascimento religioso estavam os que se voltaram para o platonismo em união dos conceitos de uma religiosidade antiga, principalmente o cristianismo. Este neoplatonismo renascentista, de espécie cristianizada, teve em Marsílio Ficino (1433-1499) um grande expoente.

Como já dito, pouquíssimos são os trabalhos acadêmicos sobre Leão Hebreu no Brasil, e quando ocorrem primam pela análise literária na composição dos Diálogos de Amor. Neste mister, destacam-se a dissertação de Paula Domingues Tavares (2011), intitulada Saber o amar: Os Diálogos de Amor de Leão Hebreu, e o livro de Luiz Roberto Alves (1997), Diálogos de Amor: humanismo e exilio em Jehuda Abravanel. Valemo-nos deles, inicialmente, para entender por que a construção do gênero literário esboçado por Leão Hebreu fez a escolha do amor como temática central de sua principal obra. 
Segundo Paula Tavares, as provas de que a obra de Ficino foi uma das principais obras de consulta platônica para Leão Hebreu está na forma 'espelhada' de como O Banquete de Platão foi lido e citado nos Diálogos de Amor, visto que $O$ Livro de Amor nada mais é do que um comentário ao Symposium, distribuído em sete discursos (TAVARES, 2001, p. 56,57). Assim, sugere a autora, Leão Hebreu faz uso da leitura de Ficino para interpretar Platão.

\section{Leão Hebreu frente à tradição: convergência e divergências interpretativas de $O$ Simpósio de Platão.}

Importa agora considerar a assimilação do amor como conteúdo discursivo, importante característica na obra de Leão Hebreu. Valemo-nos, então, da proveitosa obra de Alfredo Lacruz (2006), El Amor: de Platón a boy, em que ele apresenta uma análise histórica do tema 'amor' desenvolvido nas obras de Platão, Ficino e Leão Hebreu.

Apresentando a recepção do amor desde os tempos antigos até o século XX, Lacruz (2006) permite-nos entender o uso do conceito no entendimento dos renascentistas, época da produção dos Diálogos de Amor. Para ele, desde o período patrístico as concepções e os sentidos dos termos gregos philia e ágape, e uma versão cristianizada de eros, já começavam a se harmonizar. Não sem disputa, pois enquanto Agostinho e Tomás de Aquino buscavam atribuir uma conotação de amizade e amor verdadeiro, esses termos ainda eram confundidos com ação apetitiva, um ato individual e egoísta, desvinculando a vontade de seu objeto de desejo (LACRUZ, 2006, p. 124,125). Passavase, então, a debater a estrutura essencial do ato amoroso e a dinâmica de como se desenvolvia o amor pessoal como ato apetitivo. Esclarece Lacruz os meandros desse debate:

A adequação ou semelhança prévia entre o sujeito e o objeto, a presença intencional do objeto ao sujeito, a unidade afetiva entre os que se amam, o êxtase e a existência de si no outro, os frutos do amor em si mesmo e no rosto do outro. (LACRUZ, 2006, p. 125)

Em meio aos embates para a compreensão ocidental do termo, estava posta a discussão sobre se era possível "dar-se amor dirigido a um bem útil ou se há de ser qualificado sempre como desejo egoísta recíproco" (LACRUZ, 2006, p. 125). E enquanto a teologia trazia o sentido do termo para a definição de caridade, numa expressão de amor a Deus e às suas criaturas, o que adquiriu uma conotação sobrenatural, principalmente quando aplicado ao matrimônio como representação disto na união dos cônjuges, a filosofia, por seu turno, 
preferiu tratar o amor como amizade entre pessoas de sexo distinto. Enquanto a teologia retira sua interpretação de amor das páginas das Escrituras Sagradas, a filosofia toma o amor nas relações amistosas a partir das "determinações tipológicas expostas pelos clássicos gregos e romanos” (LACRUZ, 2006, p. 126).

$\mathrm{O}$ amadurecimento destes conceitos nascidos na Patrística, e consolidados na Idade Média, permitiu que a Renascença fosse palco para a resolução das tensões "entre os amores dirigidos ao terreno e ao divino, entre as tendências mais sensíveis e as mais espirituais, entre a natureza humana ferida pelo pecado e a graça divina" (LACRUZ, 2006, p. 126, 127). Chegandose, então, ao entendimento do 'amor cortês', que objetiva redimir o sensível por meio de uma idealização, e depois "[às] teorias renascentistas, como a de Leão Hebreu ou G. Bruno, que seguirão o caminho da 'naturalização' do corporal" (LACRUZ, 2006, p. 127).

Enfim, o amor mostrou-se como "princípio e fundamento" (LACRUZ, 2006, p. 128) para a formulação das instituições humanas, quer civis ou eclesiásticas. Na Patrística, a distinção entre eros e ágape firma, esse último, como condição vinculante da igreja; a relação matrimonial consolidou-se no conceito de amor; a amizade modelou as concepções de vida monástica e as interações sociais, e em muitos momentos evitou a desestruturação política dos povos. "Como em todos os tempos, na época Patrística e na Idade Média, o amor se considerou decisivo para a vida pessoal, social e eclesial" (LACRUZ, 2006, p. 128).

Conclui Lacruz (2006) a sua análise destacando que embora as teorias de amor encontradas na baixa Idade Média e início da Modernidade não tenham sido sempre entendidas como forma de realização e aperfeiçoamento, outrossim, foram capazes de "integrar harmonicamente lucidez e paixão, êxtase e permanência, entrega e reciprocidade” (LACRUZ, 2006, p. 129), convertendo o amor em 'loucura' e ‘consumação' dos que amam. Eis aqui a dinâmica do amor entre Fílon e Sofia encontrada no Diálogos de Amor.

Passemos, então, a entender O Livro do Amor, obra de Marsílio Ficino, inspirado em $O$ Banquete, de Platão e inserido nesse contexto, que figura entre as principais fontes de Leão Hebreu na confecção dos Diálogos de Amor, juntamente com o texto do discípulo de Sócrates.

Os textos integrais gregos que traziam a obra de Platão chegaram a Ficino para traduzi-los ao latim como parte do projeto de Cosme de Médici em financiar a fundação de um centro para estudos platônicos, a chamada Academia Platônica de Florença. A ideia de resgatar Platão ao Ocidente não 
aconteceria sem que bizantinos convocados ao Concílio de Ferrara e Florença (1438-1439) não estivessem ali, disponibilizando os textos e proferindo palestras e cursos no período dos colóquios eclesiásticos. Segundo Talyta Carvalho (2012), esboçando tese do especialista em período renascentista, Paul Oskar Kristeller, à medida em que é inegável a influência de Agostinho nas obras de Nicolau de Cusa e Marsílio Ficino, convém destacar que a presença de Platão na obra desses pensadores deve-se principalmente ao tesouro filosófico preservado por Bizâncio (CARVALHO, 2012, p. 47,48). Trata-se, assim, de mais do que um comentário. Os esforço de Ficino, integrado ao contexto da Academia, era a restituição de uma tradição platônica em seus aspectos ontológicos, cosmológicos, psicológicos e estéticos.

O comentário de Ficino a $O$ Banquete de Platão era sua homenagem a quem chamava "pai dos filósofos" (FICINO, 1996, p. 33). Repetindo a prática anual do grande aluno de Sócrates, nove convivas platônicos, entre eles o próprio Ficino, reúnem-se no campo de Careggi ${ }^{8}$ para celebrar a memória daquele que nasceu e morreu em mesma data, 7 de novembro. Platão, segundo Ficino, "colocou-se à mesa no banquete, e, depois de removidas as iguarias, expirou.” (FICINO, 1996, p. 33). Despediu-se aos 81 anos de idade e, desde então, os antigos platônicos, até ao tempo de Plotino e Porfírio, celebram esta data anual com idêntico comensal.

Em imitação a esta prática, Ficino, considerado "o principal platônico de sua época" (CARVALHO, 2012, p. 49), inicia O Livro do Amor, reconhecendo o mérito de Lourenço de Médici em resgatar em seu tempo este antigo costume dos filósofos, e entregar as providências de fazê-lo ao seu despenseiro, Francisco Bandino. Disse Ficino no Proêmio da obra:

Removidos os festins, Bernardo Núcio tomou o livro de Platão, que se intitula Convívio, sobre o Amor, e leu todas as orações deste Banquete. Nestas leituras pediu que os outros convivas narrassem cada um uma oração. Todos aceitaram. E, lançada a sorte, aquela primeira oração de Fedro coube a João Cavalcanti expô-la. A oração de Pausânias, ao teólogo Antônio; a do médico Eriximaco, ao médico Ficino; a do poeta Aristófanes, ao poeta Cristóvão; a do adolescente Agatão, a Carlos Marsupino. A Tomás Bêncio foi dada a discussão

A Academia de Careggi, idealizada por Cosme de Medici, constituía-se como um espaço de reflexão, não oficial, que perdurou durante todo o Renascimento. Nela, religiosos, poetas, comerciantes, personalidades do Estado, compartilhavam crenças que misturavam Platão, mistérios, ritos caldaicos, neoplatonismo, estoicismo, cristianismo, entre outras formas de pensamento como parte de um movimento de renovatio humanista. Sobre o tema, conferir: ARDURA, R.V, Marsilio Ficino, De Amore, Madrid: Tecnos 1996, p. XII (Introdução). 
de Sócrates, e, então, a de Alcebíades, a Cristóvão Marsupino. Assim, todos aceitaram a sorte. Mas, o bispo e o médico, impelidos a se retirarem, um para o cuidado dos espíritos e o outro para o dos corpos, legaram a João Cavalcante [sic] expor as suas partes. Os outros a ele se voltaram e se calaram atentos para ouvi-lo. Então, assim, foi exortado aquele herói. (FICINO, 1996, p. 34)

A temática do amor, em suas várias faces, era algo corriqueiro na literatura italiana, no entanto, com Ficino, o amor assume seu aspecto filosófico mais próprio e, também, permite a instauração de um gênero literário que acabará somente no século XVII (ARDURA, 1996, p. XIX)99. Nesse mesma perspectiva, Alfredo Lacruz afirma que, em Ficino, o amor tinha por finalidade restaurar a realidade, pois, concebia ele, o amor seria o elemento para reconduzir o homem na subida pela escada dos níveis decrescentes que desciam de Deus à matéria. Restabelecendo esta união e ordem do mundo, a alma encontraria redenção (2006, p. 113,114) ${ }^{10}$.

A escolha pelo diálogo como método retórico próprio de sua época, confere aos Diálogos de Amor sua qualidade reprodutora, posto que na interação dialogal há maior fecundidade filosófica. "O diálogo é a possibilidade de fazer a 'vivida riproduzione', a assunção da diversidade que supera o mero jogo retórico para contribuir à sua teoria.” (ALVES, 1997, p. 105).

A este fim o Renascimento italiano bem se serviu do neoplatonismo para reinterpretar a estrutura do universo, focando no amor "como uma Força cósmica, a condução originária da ordem, da unidade, a finalidade do mundo" (LACRUZ, 2006, p. 113). Ficino a isto também aludiu, dedicando o item IV.6 de seu Livro do Amor a uma tal proposta, como declara o subtítulo mencionado: "O Amor reconduz as almas ao céu, distribui graus de beatitude, dá o gozo eterno" (FICINO, 1996, p. 74-76). Restaurando-se as ideias cósmicas por meio do amor, restaurar-se-ia a estrutura da ordem civil. O Renascimento carecia da teoria do amor.

Eis postas aí as questões que permeiam o Diálogo Primeiro na opus magnum de Leão Hebreu, onde se discute a relação entre o amor e o desejo, pois enquanto Sofia duvida do modo como é amada, Fílon tenta convencê-la de que amar e desejar não são afetos contrários, mas uma e mesma intenção.

Neste particular, na relação do amor que conduz à união com o eterno,

\footnotetext{
9 Rocio de la Villa Ardura é categórico ao afirmar que, somente I dialoghi d'amore de Leão Hebreu, dista, em originalidade, da influência completa de M. Ficino (ARDURA, 1996, p. XIX).

10 Seguramente uma decisiva influência neoplatônica pseudo-dionisiana presente ao longo dos Diálogos.
} 
Ficino e Leão Hebreu se esmeram ambos na obra platônica. Nas palavras de Donaldo Schüler:

No Banquete, Platão define a vontade de procriar como desejo de imortalidade. Eros vincula-se à dialética e à história. O discurso dos sofistas é estático, morto. Não cria nem produz, está fora da história. O discurso vivo é o que produz e se reproduz. Reproduz-se criando outros discursos. Surge o discursar sem fim. $\mathrm{O}$ enunciado fecundo gera outros enunciados. $\mathrm{O}$ caminho à episteme é dialético. A dialética de Platão é erótica, o prazer não está excluído de seus processos de investigação. Os que procriam para sobreviver adiam a morte. Platão desloca a criação, da carne para o discurso. O discurso erotizado cria não a filosofia austera, mas a filosofia apaixonada. (PLATÃO, 2014, p. 9)

Daí se afirmar que é o amor que germina, fecunda força à estrutura argumentativa nos três discursos da obra de Leão Hebreu. O amor multiplica os discursos, fecunda os Diálogos de Amor. E em Leão Hebreu esse amor é do tipo transcendente ao mundo, visto como "um princípio localizado no domínio das ideias, mas sobretudo como força universal e imanente a repassar todos os degraus na harmonia do ser" (ABRAVANEL, 2001, p. 50,51). Percebe-se aqui neste particular de harmonização uma aproximação com a forma como Ficino entendia o amor como meio de subir degraus da existência desde a matéria até Deus.

Reconhecendo-se a aproximação dos Diálogos de Amor com O Banquete de Platão, e também o seu débito ao Livro do Amor de Finico, necessário é agora entender a estrutura na qual foi composta a obra de Leão Hebreu.

\section{Estrutura dos Diálogos de amor}

No artigo intitulado Isaac e Yebudah Abravanel e o Diálogo com o Cristianismo, o pesquisador James Novoa (2009a) discorre sobre a intencionalidade de Leão Hebreu em expressar seu elaborado pensamento de tradição judaica numa língua que primeiramente favorecesse a recepção de sua obra "num âmbito cristão da Europa Renascentista" (NOVOA, 2009a, p. 83). ${ }^{11}$ Ressaltando esse significado, o estudioso português afirma:

O facto da língua em que aparecem [os Diálogos de Amor] ser o vulgar italiano não é um facto banal. É uma questão que ainda divide os estudiosos, mas

\footnotetext{
11 À parte o debate sobre qual língua serviu para o registro original dos Diálogos de Amor, temse por consenso que as principais traduções da obra foram as versadas em italiano (1535), francês (1559), latim (1564), espanhol (1568) e, mais recentemente, em português (2001).
} 
cada vez a opinião dos especialistas é que Abravanel teria escrito a sua obra em língua italiana, contra a tese de outros que sugerem o hebraico, espanhol ou o latim como as línguas originais a partir das quais a obra foi traduzida. O peso da evidência parece sustentar razoavelmente a ideia que Leão Hebreu teria "plasmado" a sua obra, com a ajuda de colegas doutos, na língua do país em que se achava e que depois teria sido submetida a várias revisões e transformações até alcançar a forma que teve quando saiu do prelo de António Blado. (...) Estamos, literalmente, perante uma obra singular e única. Uma obra em que um Judeu de cultura e formação tradicional hebraica sefardita, mas também humanística, decide partilhar o seu saber com o mundo cristão por meio de um texto escrito na língua do país em que se achava e no gênero literário de prestígio do momento, o diálogo (NOVOA, 2009a, p.85,86) ${ }^{12}$.

A dedicatória que acompanha os Diálogos de Amor é outro tema também de incerta explicação. Seu editor, o sienense Mariano Lenzi, dedica a obra de Leão Hebreu à sua amada, "Excelsa Senhora D. Aurélia Petrucci” (ABRAVANEL, 2001, p.59). O texto é um pleito de dupla paga, em distinguir a amada com esta prova de devoção, e em granjear "o reconhecimento de Mestre Leão; porque, tendo eu arrancado das trevas em que jaziam sepultos e de certo modo trazido à luz clara do dia esses seus divinos DIÁLOGOS que encomendei ao nome de tão excelsa Senhora (...)" (ABRAVANEL, 2001, p. 60) ${ }^{13}$.

Noutra obra sua, o renomado filósofo português delimita a estrutura interna da obra de Leão Hebreu, afirmando que "três motivos dominam nos Diálogos: a prolixa interpretação astrológica, um platonismo, quase de discípulo, e o amor, fulcro de todo o livro, erigido em princípio universal" (DE CARVALHO, 2013a, s.p.) $)^{14}$. Dada a variada abordagem temática exposta

12 Novoa ainda destaca que houve um certo 'esquecimento proposital' dos Diálogos de Amor pelo fato de terem sido escritos por um judeu sefardita. E que a obra de Leão Hebreu só foi devidamente 'judaizada' quando surgiu como referência num texto latino de Giovanni Carlos Saraceno (Basileia, 1587), "numa colecção de textos cabalísticos [, chamada De Arte Cabalistica, de Johannes Reuchlin,] que incluíam aquela fonte [os Diálogos, e] que seria fundamental para o cabalismo cristão" (NOVOA, 2009a, p.84).

13 A produção de obras literárias por encomenda, a serem assumidas e dedicadas por terceiros não era algo incomum. Joaquim de Carvalho destaca que a edição espanhola de 1590 foi incluída no Índice de Livros Proibidos (Index Librorum Probibitorum), com isso a obra de Leão Hebreu foi legada ao esquecimento até que estudiosos dos sec. XVII e XVIII voltaram a revisitá-la (DE CARVALHO, 1918, p. 36).

14 A expressão aqui mencionada foi extraída de fonte de pesquisa em sítio eletrônico dedicado à obra de Joaquim de Carvalho, conforme indicada nas referências deste trabalho. No mencionado sítio não há indicação de numeração de páginas. 
nos Diálogos de Amor, as argumentações em boca de Fílon e Sofia, o amante e sua amada, fazem o transcurso em que abordam o amor em seus aspectos ontológico, cosmológico e teológico, distribuídos respectivamente nas três divisões do livro.

O Diálogo Primeiro da obra de Judá Abravanel é dedicado à relação entre o amor e o desejo; uma tentativa de atingir consenso e sentido comum entre esses termos a partir das afirmações expressas pelos dialogantes. Sobre isto, ressalta Luiz Alves:

Dialoga-se intensamente para dizer que amor e desejo são a mesma coisa, em jogo contraditório de parte dele [Fílon] e máxima agudeza de parte de Sofia, mesmo porque, ao ser chamado por Sofia para o quotidiano, o discurso de Fílon sobre o amar e o desejar não convence, organizando-se melhor quando fala "universalmente". (ALVES, 1997, p. 106)

Resumidamente, é possível perceber cinco temas expostos no correr do Diálogo Primeiro que se alternam, de forma circular, no movimento entre o natural e o transcendental e de volta ao natural: 1) Fílon expressa seu desejo por Sofia; surgem definições sobre o amor e o desejo, numa tentativa de superar divergências entre os interesses dos amantes; almeja-se, assim, uma unidade interpretativa que favoreça a consumação do amor (ABRAVANEL, 2001, p. 6369). 2). Vencidas estas etapas, são esboçadas teorias que exprimam o exercício do amor por meio de uma virtude ética dividida em três categorias: o útil, o deleitável e o honesto (ABRAVANEL, 2001, p. 70-85). 3). Seguem-se, então, argumentos que promovem a transcendência ao divino, um entendimento sobre o amor de Deus e de como este deve ser o bem mais desejado pelos amantes (ABRAVANEL, 2001, p. 86-88). 4) Os conceitos tomam direção às coisas naturais e discorre-se sobre a beatitude humana como ação última da alma em direção a Deus (ABRAVANEL, 2001, p. 89-97). 5) Agora os amantes voltam-se finalmente para debater como consumar o amor humano e vivenciar o mundo das paixões (ABRAVANEL, 2001, p.98-111).

O colóquio inicial entre Fílon e Sofia objetiva convergir conceitos e estabelecer consenso entre ambos, embora isto não aconteça até o final da obra. Enquanto Fílon afirma que conhecer Sofia provoca nele amor e desejo, Sofia entende que amor e desejo são incompatíveis e, portanto, ele não poderá conhecê-la de fato. Segundo Sofia, onde houver amor, não haverá mais desejo, posto que não se precisará mais desejar o que se tem. Assim, a relação entre eles seria deficiente. Explica Sofia: 
SOFIA - É um falar impróprio, esse dizer amar, isto é, querer ter a coisa, quando e pretende dizer desejá-la: porque o amor é da própria coisa amada, e o desejo é de a ter ou conseguir; nem parece que possam conciliar-se amar e desejar. (ABRAVANEL, 2001, p. 64)

Noutro trecho, Sofia continua a tergiversar, insistindo em sua argumentação:

SOFIA - Compreendi o teu raciocínio, que me agrada bastante. Mas eu vejo muitas coisas que têm ser próprio real e que desejamos quando as não temos; no entanto, não as amamos enquanto as não possuímos: por exemplo, as riquezas, uma casa, uma vinha, uma joia, as quais, quando estão em poder de outrem, se desejam, e não se amam por pertencerem a outros; mas, depois de alcançadas, enquanto vem a faltar o desejo delas, tornam-se objecto de amor. Portanto, antes de serem obtidas, são apenas desejadas e não amadas; depois de adquiridas, são apenas amadas, e não desejadas. (ABRAVANEL, 2001, p. 69,70)

$\mathrm{Na}$ falta de acordo, acode-se às definições dos conceitos, e Fílon passa a falar "em termos mais universais" (ABRAVANEL, 2001, p. 64). Seus argumentos apelam à lógica e demonstram a contradição de Sofia em não se permitir amar e desejar:

FÍLON - Os teus argumentos, ó Sofia, mais demonstraram a sutileza do teu engenho que a verdade da tua opinião; porque, se não amarmos aquilo que desejamos, desejaremos o que se não ama, e por conseguinte aquilo que se aborrece e detesta, o que não poderia representar maior contradição. (ABRAVANEL, 2001, p. 64)

O centro do debate desenvolve-se, então, em distinguir as três espécies de amor e desejo: as que são amadas e desejadas ao mesmo tempo, as que são amadas e não desejadas, e as que são desejadas e não amadas. E o primeiro esforço está em definir o amor e o desejo:

SOFIA - Explica-me a diferença que existe entre os dois, isto é, entre amar e desejar. E para que melhor te possa entender, gostaria que me definisses o amor e o desejo de forma a poderes abranger nessa definição todas as suas três espécies.

FÍLON - Não é tão fácil, como te parece, definir o amor e o desejo com 
definição acomodada a todas as suas espécies, pois a sua natureza se encontra com aspecto diverso em cada uma delas; nem consta que os filósofos antigos lhes tenham dado tão ampla definição. A julgar; no entanto, por aquilo que me parece conforme com a presente exposição, pode definir-se o desejo como afecto voluntário do ser, ou de possuir a coisa tida por boa e cuja falta se sente, e definir-se o amor como impulso voluntário a fruir com união a coisa tida por boá. Por estas definições não só conhecerás a diferença entre tais afectos da vontade (que um, como te disse, é de gozar a coisa pela união, e o outro, de o ser ou de a ter), mas ainda verás por elas que o desejo se refere a coisas que faltam. Todavia, o amor pode ser das coisas que se têm, e ainda das que se não têm, pois que o gozar pela união pode ser afecto da vontade tanto em relação às coisas que nos faltam, como àquelas que já temos, porquanto tal disposição não pressupõe hábito nem falta alguma, antes é comum a ambos. (ABRAVANEL, 2001, p. 70)

Durante todo o percurso investigativo nos questionamentos de Sofia, Fílon se esmera em definir amor e desejo sob as três espécies de coisas amáveis, qualificadas como úteis, deleitáveis e honestas, uma notória influência aristotélica sobre Leão Hebreu, visto que a obra de Aristóteles contribui para o aspecto civil do Renascimento (SAVOYE DE FERRERAS (1985, p. 170). ${ }^{15}$ Em sua busca pelas coisas amáveis, os amantes dialogais descobrirão que "o imenso Deus tanto se ama quanto se conhece. (...) Ele é digno de ser amado, mas apenas quanto, no acto de amor, pode expandir-se n'Ele" (ABRAVANEL, 2001, p. 88).

Partindo do conhecimento de Deus como objeto e sujeito do amor, Sofia começa a entender a relação entre amor e desejo:

SOFIA - Mas será possível conhecer um objecto sem que a pessoa que o conhece o possa abarcar?

FÍLON - Basta que se compreenda a parte que do objecto se conhece, pois quem conhece compreende o conhecido na medida do seu poder cognoscitivo, e não segundo o do conhecido (...). (ABRAVANEL, 2001, p.88)

Para dirimir as divergências semânticas e filosóficas quanto à possibilidade de unir amor e desejo, Fílon responde aludindo a Deus a condição de sujeito e objeto do amor:

15 Referindo-se à análise que Andrés Soria Olmedo faz dos Diálogos de Amor, Savoye de Ferreras (1985, p. 170) entende que esta classificação deve-se à influência aristotélica da obra Ética a Nicômaco sobre Leão Hebreu. 
FÍLON - Sendo Deus o verdadeiro e único objecto de nossa felicidade, nós O amamos com conhecimento e amor. Os doutos foram discordantes a respeito destes dois actos: isto é, se o próprio acto da felicidade é conhecer Deus, ou amá-lo. Mas para ti bastará saber que para a beatitude são necessários um e outro acto. (ABRAVANEL, 2001, p.97)

Como disse Fílon: "O perfeito e verdadeiro amor, como aquele que te consagro, é pai do desejo e filho da razão, e em mim o produziu a recta razão cognoscitiva" (ABRAVANEL, 2001, p.105). O amor, conduzido pela razão, é, assim, produtor do conhecimento. Conhecemos e somos levados pela lógica, derivada deste conhecimento, a amar. Inicia-se, assim, o conceito de amor intelectual ${ }^{16}$ proposto por Leão Hebreu no correr de sua obra. Vale aqui ressaltar a observação de Paula Tavares:

Sofia, durante todo o diálogo [primeiro], argui o outro personagem a debater questões complexas em si, não apenas sobre o amor e o desejo, mas também algumas do tipo "E é possível que um homem tenha este conhecimento de todas as ciências?", entre outras, ao estilo dos diálogos platônicos. (TAVARES, 2011, p. 33) ${ }^{17}$

Por fim, é de se lembrar que os Diálogos de Amor estão arranjados argumentativamente para concluir no Diálogo Terceiro, que se romperá com a definição do amor divino como a "inclinação da sua belíssima Sapiência

16 Para mencionar o que será melhor visto no estudo do Diálogo Terceiro, o amor intelectual ou amor intellectualis no pensamento Leão Hebreu refere-se a intelecto puro, quando a alma passa a conhecer sub specie aeternitatis, conceito assemelhado ao encontrado no livro $\mathrm{V}$ da Ética de Espinosa, o que lança suspeita se o português teria influenciado o holandês (DE CARVALHO, 2013b, s.p.). Para um estudo sobre o sentido de amor intellectualis como ensino provindo de estudos cabalísticos sobre a filosofia medieval, ver HARVEY, Warren Zev. Idel on Spinoza. Journal for the Study of Religions and Ideologies, v.6, n.18, p. 88-94, 2007. Disponível em: <www.jsri.ro/new/?download=18_JSRI_Zev_Harvey_Warren.pdf>. Acesso em: 25 jul. 2016. Sobre a influência dos Diálogos de Amor na obra de Espinosa, Ulysses Pinheiro (2015, p. 231) entende que há traços do pensamento de Leão Hebreu nos escritos de Espinosa. Segundo Pinheiro, Espinosa teria três fontes de apropriação do platonismo: a primeira seria sua forte herança renascentista, a segunda, a influência recebida de Descartes e os cartesianos, e a terceira viria de escritores cabalísticos. Em sua maturidade, Espinosa modificou o neoplatonismo cabalístico em platonismo cartesiano. Por meio desta última influência, entende Pinheiro, as teses de Leão Hebreu estão presentes na obra de Espinosa.

17 O referido questionamento de Sofia, extraído dos Diálogos de Amor, está registrado em Abravanel (2001, p.94). 
para a sua imagem, isto é, para o universo por Ele produzido, com retorno deste à união com a sua suma Beleza (...)" (ABRAVANEL, 2001, p.408). Percebe-se, então, a importância do Diálogo Primeiro como base para todo o arrazoado de amor proposto por Leão Hebreu.

O Diálogo Segundo, voltado para o estudo da universalidade ou da comunicação do amor e dedicado à cosmologia, é, na opinião de Luiz Alves (1997), melhor analisado sob uma forma jurídica, visto que "enfatiza o gênero judicial e pretende produzir a metáfora continuada da anima mundi” (ALVES, 1997, p. 113). Ali, objetiva-se ampliar o sentido já apresentado entre amor e desejo, como iniciado no diálogo anterior.

FÍLON - Se queres que falemos do nascimento do amor, convirá que, na presente prática, te informe primeiramente da comunhão do seu ser e da sua ampla universalidade; depois, noutra oportunidade, falaremos do seu nascimento. (ABRAVANEL, 2001, p. 116)

Este diálogo pode ser resumidamente entendido em quatro divisões: 1) Reflexões sobre as formas como ocorre o amor no mundo inferior, sentimento comum a varão, mulher, jovem, velho, criança e até animais; este amor também se espalha na alma do mundo e pode ser conhecido na forma como se relacionam os quatro elementos: terra, água, ar e fogo (ABRAVANEL, 2001, p. 115-129). 2) O amor também pode ser comunicado universalmente no conhecimento do mundo celeste, posto que também há união conjugal entre Terra e Céu, sendo este o marido e aquela, a mulher; eis porque o homem é o microcosmo do universo e nele conjuntamente estão representados e unidos o macho e a fêmea; sua cabeça é simulacro do mundo espiritual e por meio dela os antigos exprimiam poemas que encerram os sentidos literal (histórico) e moral (teológico) de suas realidades, estimulando princípios científicos por meio de seus mitos; intercambiavam filosofia moral com filosofia natural, quando de fato estavam expressando teologia de Deus e seus Anjos (ABRAVANEL, 2001, p.130-157). 3) Entre os mitos da Antiguidade Clássica, destacam-se aqueles que reafirmavam o anseio erótico como forma de consumação do amor, e o texto discorre sobre os enamoramentos dos deuses como estudados na mitologia, nas constelações e no zodíaco (ABRAVANEL, 2001, p. 158-199). 4) O diálogo volta a descender quando retoma reflexões sobre o amor no 
âmbito das criaturas corporais e sua manifestação no mundo inteligível (ABRAVANEL, 2001, p.200-211) ${ }^{18}$.

O Diálogo Terceiro começa a ser organizado ainda dentro do Segundo, "porque as imagens associadas à visão são crescentes, fortalecidas pela criação de um processo alegórico claramente assumido” (ALVES, 1997, p. 113). Ressalta Vila-Chã que no Diálogo Terceiro Leão Hebreu dedica-se a apresentar e debater a "natureza quase teológica acerca das origens do amor no universo” (ABRAVANEL, 2001, p. 50). Com um conteúdo filosóficoteológico quase exclusivo, o Diálogo Terceiro foi interpretado por Luiz Alves (1997, p. 118) como texto distribuído pelos seguintes tópicos: 1) A sensualidade com direito a ser valor; 2) a mulher como contraponto para a visibilidade da inteligência; 3) O duplo como interrogação ao estabelecido; 4) $\mathrm{O}$ desejo como processo pedagógico.

Somado a esse entendimento, é possível ler o Diálogo Terceiro em dez divisões temáticas: 1) A importância dos sentidos como canais de interpretação intelectiva do mundo, relacionando o mundo natural com uma percepção espiritual, a partir de uma iluminação provida pelo intelecto divino (ABRAVANEL, 2001, p. 215-235). 2) A participação do intelecto à alma humana; reflexões sobre o amor intelectual (ABRAVANEL, 2001, p.236-238). 3) As inquietações da alma diante do amor não correspondido; prelúdio dos efeitos do amor sobre os amantes, tema que seria expandido num provável quarto diálogo (ABRAVANEL, 2001, p. 239-245). 4) Inicia-se o debate sobre a definição da essência do amor e qual seja sua natureza, que levará às questões estéticas e metafísicas relacionadas: o sentido do bom e do belo na deleitação do amor (ABRAVANEL, 2001, p. 246-267). 5) Questiona-se o nascimento do amor, se ele teve origem (ABRAVANEL, 2001, p. 268-273). 6) Pergunta-se quando o amor nasceu, e define-se que o primeiro amor é do primeiro amante ao primeiro amado, tudo reunido em Deus (ABRAVANEL, 2001, p. 274-296). 7) Responde-se onde nasceu o amor (ABRAVANEL, 2001,

18 Há ainda outro destaque importante a fazer sobre o Diálogo Segundo. Na avaliação de James Novoa (2009a), esta divisão dos Diálogos de Amor é uma tradução quase literal da De Genealogia deorum de Giovanni Bocaccio, onde surgem deuses gregos representando uma "teoria da presença do amor divino no universo segundo a quádrupla exegese dos textos sagrados e profanos defendidos pela patrística e pelo pensamento medieval cristão: historial, alegórico, literal e moral" (NOVOA, 2009a, p. 89). Para o pesquisador, quando essas divindades gregas foram inseridas nos Diálogos de Amor, a obra de Judá Abravanel se tornou familiar para os cristãos que a estavam lendo no início do século XV. 
p. 297- 385). 8) Deseja-se saber de quem nasceu o amor (ABRAVANEL, 2001, p. 386-395); e 9) Atende-se ao um duplo questionamento sobre o por quê e para que fim nasceu o amor (ABRAVANEL, 2001, p.396-413). 10) Por fim, a consumação do amor natural é adiada mais uma vez dada a desconfiança que se estabelece sobre a sinceridade e voluntariedade nos interesses desse amor (ABRAVANEL, 2001, p. 414-417).

Entende Paula Tavares (2011, p. 35) que o Diálogo Terceiro é o que "pode ser considerado o mais específico quanto ao tema, [pois] mostra os conhecimentos do personagem Filo (sic) sobre a origem do amor." Aqui, o texto abre com os amantes se expressando em maior intimidade nas conversações, pois já se dão a conhecer em maior intensidade pelo cortejo construído nos diálogos anteriores (ABRAVANEL, 2001, p. 215-2017). Se no início deste diálogo a amada esboça risos na argumentação de enamoramento (ABRAVANEL, 2001, p.216), mais adiante Fílon demonstra irritação pela forma como Sofia adia a consumação do amor, entendendo-a como "ambiciosa" e "venosa", já que desmerece que a causa do arrebatamento de sentidos do amante é a indiferença da amada, o vazio de amor que deveria ser correspondente (ABRAVANEL, 2001, p.239-242).

Neste último diálogo estão registradas as sete referências que Leão Hebreu faz ao Simpósio (O Banquete) de Platão (ABRAVANEL, 2001, p. 258, $271,316,323,324,325,341)$, ${ }^{19}$ detém-se ele no debate acerca do belo e do bem (ABRAVANEL, 2001, p. 258), transbordam ali os autores clássicos, quer gregos, latinos ou hebraicos, e finaliza o autor, por boca de Fílon, discorrendo sobre a antiga sabedoria cabalística, a pedido de Sofia. É, também, o Diálogo Terceiro, a composição que gerou mais controvérsia entre os estudiosos literários, dada a complexidade das fontes e grande divergência havida na crítica textual de seus manuscritos. ${ }^{20}$

\footnotetext{
19 Valemo-nos aqui de uma oportuna tabela que agrupa obras e autores citados por Leão Hebreu nos Diálogos de Amor, compilada e anexada ao texto da pesquisadora Paula Tavares (2011, anexos).

20 James Novoa (2009b) desenvolveu precioso estudo sobre a crítica textual do Diálogo Terceiro no artigo Appunti Sulla Genesi Redaz̧ionale dei Dialogbi D'Amore di Leone Ebreo alla luce della Critica testuale Attuale e la Tradizione Manoscritta del suo Terzo Dialogo. Andrés Olmedo (2009) registra que em 1525 já se falava da existência dos Diálogos de Amor por meio de diversas cópias manuscritas que circulavam pela Itália em linguagem toscana; veja-se, por exemplo, o registro que Cervantes faz no prólogo do Quixote. Disponível em: <http:// www.biblioteca.org.ar/libros/134819.pdf>. Acesso em: 25 mai. 2016.
} 
Como um amante a cumprir promessas de amor à amada, Fílon é fiel em retornar aos temas anteriores (relação amor/desejo e universalidade do amor), tal como prometido a Sofia, porém se detém no motivo central deste Diálogo, a origem do amor. E este tema central no Diálogo Terceiro, do qual Fílon não cede em tergiversar, mostra-se como possível chave interpretativa de todo o pensamento de Leão Hebreu, e deve fundamentar o capítulo seguinte da presente pesquisa.

\section{Considerações finais}

O último diálogo entre Fílon e Sofia tem sua importância, principalmente, por lançar luz ao caráter ousado de Leão Hebreu que propõe uma literatura de amor que encerra uma profunda originalidade. Deste modo, posto a escolher entre a Suma Sapiência e o Sumo Belo, Fílon faz opção pelo ensino mosaico do qual, segundo ele, o ensino platônico é dependente e dele deriv

FÍLON - Sendo eu moisaico [sic] na sabedoria teologal, cinjo-me a este segundo caminho, porque é realmente teologia moisaica; e Platão, como pessoa que tinha desta antiga sabedoria maior informação que Aristóteles, seguiu-a. Aristóteles, cuja visão das coisas abstractas foi um tanto mais acanhada, porque não tinha os ensinamentos dos nossos teólogos antigos, como os teve Platão, negou o que não pôde ver por estar oculto, juntou à Suma Sapiência a Primeira Beleza e, saciado desta o seu intelecto, sem olhar mais além afirmou ser aquela o primeiro princípio incorpóreo de todas as coisas. Platão, que tinha aprendido dos velhos no Egipto, pôde levar para mais longe a sua percepção, embora não conseguisse ver o princípio oculto da Suma Sapiência, ou Primeira Beleza, e fizesse dela segundo princípio do universo, dependente do Sumo Deus, primeiro princípio de todas as coisas. Embora Platão fosse mestre de Aristóteles durante tantos anos, nessa matéria divina o dito Platão, como discípulo que fora de nossos avoengos, aprendeu de melhores mestres do que Aristóteles [aprendera] dele, porque o discípulo do discípulo não pode alcançar o discípulo do mestre; e acresce que, apesar de Aristóteles ser subtilíssimo, não creio que o seu engenho pudesse levantar-se tanto na abstracção como o de Platão, nem ele quis como os outros acreditar pelas palavras do mestre aquilo que as próprias forças do seu engenho lhe não demonstrassem.

SOFIA - Pois eu também vou atrelar a tua doutrina à platónica: entenderei o que puder, e quanto ao resto acreditarei em ti como em pessoa que vê melhor e mais além do que eu. Mas desejaria que me mostrasses onde é que Moisés e os outros santos profetas expressaram esta verdade platónica. (ABRAVANEL, 2001, p. 380) 
O fato de que em sua obra Leão Hebreu não tenha se esmerado plenamente no Banquete de Platão, antes abordado apenas algumas passagens, torna mais destacada sua grandeza e originalidade pois, ao analisar partes da espécie, Abravanel transbordou saber para discorrer sobre todo o gênero. Onde Platão foi específico, Leão Hebreu foi original em apresentar uma interpretação ampla e universal. Dialogando com fontes gregas, latinas e hebraicas, o autor dos Diálogos de Amor faz constar em sua obra cento e sessenta e oito referências a autores clássicos (TAVARES, 2011, p.79), sem mencionar as citações diretas às Escrituras Sagradas. Poucas, no entanto, foram as obras citadas, além da Bíblia. Vila-Chã as registra: de Platão, referiu-se a O Banquete, ao Fedro e ao Timeu; de Aristóteles, à Ética e à Política; de Homero, à Ilíada; de Moisés Maimônides, citou Moreh Nebuchim; e de Ibn Gabirol, De fonte vitae (ABRAVANEL, 2001, p. 44). Como disse James Novoa (2009a), "as fontes citadas explicitamente por Hebreu foram aquelas do curriculum da filosofia e do saber judaico medieval" (NOVOA, 2009a, p. 88), tornando os Diálogos de Amor a última obra da tradição filosófica medieval judaica.

Semelhante a Ficino, Leão Hebreu também via em Deus a fonte de tudo o que é criado e que a Ele prossegue em retornar. Conquanto em Ficino esta escala do ser é vencida em Cristo, a personificação do amor, algo que para o judeu Leão Hebreu não se afirmaria, ambos reconhecem em Deus a fonte geracional da vida ${ }^{21}$. Como relembra Talyta Carvalho (2012, p. 103): "Se considerarmos a ontologia de Ficino (...), sabemos que, de acordo com a hierarquia dos entes, Deus é a forma mais elevada, e, portanto, a forma mais elevada de geratio pertencerá a Deus somente." Ou, nas palavras do próprio Leão Hebreu, em seu Diálogo Terceiro:

SOFIA - Expõe, de vez, a dúvida que existiu entre os homens a respeito de quando foi criado o mundo, e saberemos a dúvida que há sobre quando nasceu o amor; depois de conhecido o problema, acharás mais depressa o caminho para a solução.

FÍLON - Vou dizer-to. Enquanto todos os homens são unânimes em reconhecer que o sumo Deus, gerador e opífice do mundo, é eterno, sem nenhum princípio temporal, estão divididos quanto ao problema da criação do mundo: se existe ab aeterno, ou só de algum tempo para cá. Muitos dos filósofos defendem que foi ab aeterno produzido por Deus e que nunca teve principio temporal, assim como nunca o teve o próprio Deus; e desta opinião

21 Em Ficino, este conceito de geratio foi aplicado na formulação de sua doutrina da Trindade (CARVALHO, 2012, p.102-105) 
é o grande Aristóteles, com todos os Peripatéticos (ABRAVANEL, 2001, p. 275, 276).

Invertendo a expectativa comum, Leão Hebreu, por boca de Fílon, propõe que a verdadeira sabedoria esboçada por Platão e, portanto, reverberada em seus seguidores seculares, teve origem na "sabedoria teologal", ou melhor, na "teologia mosaica" (ABRAVANEL, 2001, p. 380), ao que Sofia formula a inquirição de todos nós: “(...) desejaria que me mostrasses onde é que Moisés e os outros santos profetas expressaram esta verdade platónica” (ABRAVANEL, 2001, p. 380).

\section{Referências}

ABRAVANEL, Judá (Leão Hebreu). Diálogos de Amor. Tradução de Giacinto Manuppella. Coleção Pensamento Português. Lisboa: Imprensa Nacional - Casa da Moeda, 2001.

ALVES, Luiz Roberto. Diálogos de Amor, Humanismo e Exílio em Jehuda Abravanel. São Paulo: Nova Alexandria/EDUSP, 1997.

AMORIM, Juliana Horstmann. Tratados de Amor: uma análise das obras de Pietro Bembo (1505) e de Tullia d'Aragona (1547) na tradição filográfica do renascimento italiano. Curitiba: UFPR, 2010.

BEZERrA, C.C. Compreender Plotino e Proclo. Petrópolis/RJ: Vozes, 2006.

BEZERRA, C.C.; BEZERRA, J.S.C. A linguagem nupcial no Canto Espiritual de San Juan de la Cruz. Letras, Santa Maria, v. 21, n. 43, p. 223-245, jul./dez. 2011. Disponível em: <https://periodicos.ufsm.br/letras/article/view/6903>. Acesso em: 23 jan. 2017;

BEZERRA, C.C. A experiência negativa do sagrado em San Juan de la Cruz. IpotesI, Juiz de Fora, v.16, n.2, p. 215-225, jul./dez. 2012. Disponível em: <http://www.ufjf.br/ revistaipotesi/files/2011/05/CAP16-215-225.pdf>. Acesso em: 23 jan. 2017.

CARVALHO, Talyta. Fé e Razão na Renascença: Uma introdução ao conceito de Deus na obra filosófica de Marsílio Ficino. São Paulo: É Realizações, 2012.

DE CARVAlho, Joaquim. Leão Hebreu, filósofo: Para a história do platonismo no Renascimento. Coimbra: Imprensa da Universidade, 1918.

Influência dos Diálogos de Amor. In: Leão Hebreu, Filósofo? (Para a História do Platonismo no Renascimento). 2013a?. Disponível em: <http://www.joaquimdecarvalho.org/ artigos/artigo/30-Capitulo-I-Influencia-dos-Dialogos-de-Amor>. Acesso em: 27 jul. 2015.

FICINO, Marsílio. O Livro do Amor. Tradução de Ana Thereza Basílio Vieira. Niterói/RJ: Clube de Literatura Cromos, 1996.

FRADE, Florbela Veiga. Pensamento Religioso dos Judeus Portugueses de Hamburgo no Século XVII. Anais de História de Além-Mar. Lisboa: UNL. v. XII, n. 12, 2011, p. 181-212. LACRUZ, Alfredo Álvarez. El Amor: de Platón a hoy. Madrid: Palabra, 2006.

NOVOA, James W. Nelson. Consideraciones acerca de una versión aljamiada de los Diálogos de Amor de León Hebreo. Sefarad, n. 65, p. 103-126, 2005. 
A publicação dos Diálogos de Amor de Leão Hebreu no contexto romano da primeira metade do século XVI. Cadernos de Estudos Sefarditas, n.6, p.55-74, 2006.

Isaac e Yehudah Abravanel e o Diálogo com o Cristianismo. Cadernos de Estudos Sefarditas, n. 9, p. 75-92, 2009a.

. Appunti Sulla Genesi Redazionale dei Dialoghi D’Amore di Leone Ebreo alla luce della Critica Testuale Attuale e la Tradizione Manoscritta del suo Terzo Dialogo. Quaderni d'italianistica, v. 30, n. 1, p. 45-66, 2009b. Disponível em: < http://jps.library.utoronto. ca/index.php/qua/article/view/8426/5399>. Acesso em: 23 jul. 2016.

OLMEDO Andrés Soria. León Hebreo, el amor entre dos mundos. Buenos Aires: Biblioteca Virtual Universal, 2009. Disponível em: < http://www.biblioteca.org.ar/libros/134819.pdf>. Acesso em: 23 jul. 2016

PINTO, Maria José Vaz. A Recepção ou Invenção Ficiniana do “Amor Platônico". Philosophica 14, Lisboa, p. 51-44, 1999. Disponível em: <http://www.centrodefilosofia.com/ uploads/pdfs/philosophica/14/4.pdf>. Acesso em: 28 jul. 2015.

PLATÃO. O Banquete. Tradução, notas e comentários de Donaldo Schüler, Porto Alegre/ RS: L\&PM, 2014.

TAVARES, Paula Domingues. Saber o Amar: os Diálogos de Amor, de Leão Hebreu. São Paulo: USP, 2011. Dissertação para obtenção do título de Mestre em Letras Clássicas e Vernáculas.

VILA-CHÃ, João. Leão Hebreu e o Significado de sua Obra. In: ABRAVANEL, Judá (Leão Hebreu). Diálogos de Amor. Tradução de Giacinto Manuppella. Coleção Pensamento Português. Lisboa: Imprensa Nacional - Casa da Moeda, 2001.

VILA-CHÃ, João. Amor Intellectuallis? Leone Ebreo (Judah Abravanel) and the intelligibility of love. Publicações da Faculdade de Filosofia. Braga. 2006.

Submetido em: 3-9-2019

Aceito em: 26-4-2020 